\title{
Overlap Syndrome
}

National Cancer Institute

\section{Source}

National Cancer Institute. Overlap Syndrome. NCI Thesaurus. Code C116801.

An autoimmune, connective tissue disorder in which the patient exhibits features from two or more diseases. These typically include systemic sclerosis, dermatomyositis, polymyositis, rheumatoid arthritis, systemic lupus erythematosus, and Sjogren syndrome; in pediatrics the respective pediatric entities are encountered. 